\title{
Evaluation of prescription containing medication via enteral feeding tubes in an adult emergency unit
}

\author{
Inaê de Azevedo SPEZIA ${ }^{1}$ (D), Filipe Carvalho MATHEUS ${ }^{2}$ (D) \\ ${ }^{1}$ Programa de Residência Integrada Multiprofissional em Saúde da Universidade Federal de Santa Catarina; ${ }^{2}$ Departamento de Ciências \\ Farmacêuticas, Programa de Pós-graduação em Assistência Farmacêutica, Universidade Federal de Santa Catarina.
}

Corresponding author: Spezia IA, inaespezia@gmail.com

Submitted: 22-06-2020 Resubmitted: 22-06-2020 Accepted: 05-10-2020

Peer review: blind reviewers

\begin{abstract}
Objective: This study aims to evaluate medication prescriptions to be used by a feeding tube in an emergency unit, identify and classify the problems with the prescriptions and suggest interventions, done by a pharmacist, when necessary. Also aims to develop a guide with information about administering medication through the feeding tube in order to help the health care team. Methods: the study is characterized as a quantitative cross-sectional study, with data collected during March to September of 2019 at an adult emergency unit, a total of 47 prescriptions were analyzed by a pharmacist and 138 drugs were prescripted to be administered through a feeding tube. Results: A total of $18.8 \%$ of those medications presented some restriction to be administered by the feeding tube. The most common problems observed were the loss or reduction of therapeutic effect present in $61,6 \%$ of the cases, followed by drug-food interactions with $30.8 \%$. About the pharmaceutical intervention more performed was requesting to change the pharmaceutical form (36\%), followed by orientation about stop the enteral feeding (30.2\%). To the elaboration of the guide for the health care team, 181 medications standardized at the hospital were analyzed, of that 33.1\% presented some restriction to administer by feeding tube and only $35 \%$ presented another pharmaceutical form for substitution. Conclusion: it was possible to note the importance of pharmaceutical evaluation of prescriptions to identify errors and prevent future problems assuring the patient's safety. The guide elaboration sought to assist and optimize the process of medication administration by feeding tube guaranteeing the safety and effectiveness of pharmacotherapy.
\end{abstract}

Keywords: enteral nutrition, food-drug interactions, pharmacists, pharmacy service, hospital.

\section{Avaliação de prescrições contendo medicamentos administrados via sonda enteral em uma unidade de urgência e emergência adulto}

\section{Resumo}

Objetivos: o presente estudo visou analisar a presença de incompatibilidades em medicamentos prescritos via sonda enteral em uma unidade de urgência e emergência adulto, descrever intervenções realizadas e elaborar uma tabela para consulta sobre a administração de medicamentos via sonda por farmacêuticos. Métodos: trata-se de um estudo transversal quantitativo realizado em uma unidade de urgência e emergência adulto na qual foram analisadas prescrições de medicamentos por sonda enteral, durante o período de março a setembro de 2019. Foi realizada uma revisão da literatura para classificação das incompatibilidades e construção de um quadro com orientações sobre os medicamentos utilizados na instituição estudada. Resultados: Foram analisadas 47 prescrições contendo 138 medicamentos, dos quais, 18,8\% apresentava algum tipo de restrição para administração via sonda enteral. Observouse que havia risco de perda ou diminuição do efeito terapêutico em $61,6 \%$ dos casos, com base em informações da literatura. Entre as intervenções farmacêuticas mais frequentes, foi realizada a solicitação de alteração da forma farmacêutica em $36 \%$ dos casos. Dentre os 181 medicamentos padronizados na instituição, 33,1\% possuíam alguma restrição para realizar a administração via sonda e apenas 35\% apresentavam outra forma farmacêutica alternativa para substituição, sendo estas orientações indicadas no quadro de incompatibilidades. Conclusão: a avaliação farmacêutica das prescrições permitiu a identificação de problemas na prescrição e prevenção de erros. O material elaborado poderá auxiliar e otimizar o processo da administração de medicamentos via sonda, aumentando a segurança e efetividade da farmacoterapia.

Palavras-chave: nutrição enteral, interações alimento-droga, famacêuticos. serviço de farmácia hospitalar. 


\section{Introduction}

Enteral feeding tubes are devices used to supply the nutritional needs of a person who is incapable of eating or that is not receiving adequate nutritional support orally. The tubes can be classified according to their place of insertion as follows: nasogastric, nasoduodenal, nasojejunal, and percutaneous (ostomies). In addition to providing nutritional needs through enteral nutrition, oral medications are frequently prescribed in this route of administration. ${ }^{1}$

However, there are singularities associated with the use of medications via enteral feeding tubes. The presence of specific aspects related to formulations of solid oral pharmaceutical forms makes that their crushing process result in possible adverse events, exposing patients to unnecessary risks during hospitalization. By crushing a drug, its pharmacokinetic properties are changed, and it can consequently cause toxicity, gastrointestinal adverse reactions, interactions with enteral nutrition or among medications, sub-therapeutic effect, and tube obstruction. ${ }^{2}$

One of the main complications related to the use of medications via a tube is obstruction. It can occur due to the viscosity and $\mathrm{pH}$ of the solution formed after crushing, to the excipients of the medication, to the non-pause of enteral nutrition before the administration of medications, to the mixture of various crushed oral solids for administration or to the improper hygiene of the tube before and after administration. ${ }^{3}$ The reinsertion of a new tube implies discomfort for the patient, in addition to additional costs with materials and radiological exams to confirm its position. $^{4}$

Some solid oral medications have a highly technical formulation matrix, produced to guarantee a controlled release time in the organism. Controlled release formulations, such as nifedipine, when crushed, have their release control system destroyed and, as a result, a much larger amount of the drug is made available for immediate absorption, thus causing potentially serious and fatal adverse events to the patient, such as cardiorespiratory arrest due to the increased hypotensive effect. ${ }^{5}$

Additionally, medications administered via enteral feeding tubes can have interactions with the enteral nutrition and hinder therapeutic responses. Regarding the drug-nutrient interaction, phenytoin can be mentioned, which has its bioavailability reduced when administered concomitantly with enteral nutrition, leading to a sub-therapeutic effect. ${ }^{6}$ In another example, ciprofloxacin, an antimicrobial agent, when administered together with enteral nutrition, forms precipitates that prevent its absorption in the digestive tract and, consequently, has a reduced effect. A way to prevent these problems would be interrupting enteral nutrition for an hour before and after drug administration.

In order to prevent problems related to the use of enteral tubes and drug administration, the Institute for Safe Medication Practices (ISMP) listed a series of recommendations, among them, the daily evaluation of medical prescriptions containing medications to be administered by this device to avoid errors and ensure safety in the use of medications. Furthermore, it is recommended to create preventive barriers to identify medications that should not be crushed, such as warning labels. ${ }^{8-9}$
Drug administration via enteral feeding tubes must go through an analysis from the pharmacological and pharmacotechnical point of view to avoid therapeutic faults and possible harms to the patient. ${ }^{4}$ It is the health care team's responsibility to be aware of and know how to deal with this kind of situation. Additionally, pharmaceutical interventions are decisive to correct and recognize restrictions for the administration of medications prescribed via enteral feeding tubes. ${ }^{2}$

In view of the above, this study aimed to verify existing incompatibilities in prescriptions of medications administered via enteral tubes, to describe the main pharmaceutical interventions performed, and to present synthesized evidence from the literature on the safety or not of drug administration by means of enteral tube devices at an adult emergency unit located in Southern Brazil.

\section{Methods}

This is a descriptive and cross-sectional study in which second copies of the prescriptions containing medications administered via enteral tubes were analyzed in the adult emergency unit of the Professor Polydoro Ernani São Thiago University Hospital (HU/UFSC), located in Florianópolis (Santa Catarina, Brazil). The emergency unit where the study was conducted has 24 hospital beds for assistance by the Unified Health System. The sample was selected by convenience, and the medications were prescribed from March to September 2019 (6 months).

The medications prescribed via enteral feeding tubes considered for the analysis were those present in the hospital's standardization list, as resolved by the institution's Pharmacy and Therapeutics Committee (PTC). Medications that were not in the hospital standardization were excluded from the analysis.

For the identification of incompatibilities, by analyzing the medications prescribed and for elaborating the consultation material for the professionals, the following terms were searched in the literature: generic name of the medication, medicamento/drug, sonda enteral/enteral feeding, administração/administration, cateter enteral/enteral feeding tube. Texts in English, Spanish and Portuguese available for free were considered and which included content on administration viability via enteral tube, published between 2000 and 2019. The databases consulted were PubMed, Scielo, Lilacs, Medscape, Micromedex ${ }^{\circledR}$, and the electronic records of registered medications, made available by the National Health Surveillance Agency (Agência Nacional de Vigilância Sanitária, ANVISA) on a virtual platform. ${ }^{10}$

The following categories were considered for describing the incompatibilities found: (1) risk of tube obstruction; (2) loss or reduction in drug effectiveness; (3) pharmacokinetic changes, and (4) drug-nutrient interaction. In the presence of any incompatibility with the medication, pharmaceutical interventions were suggested to the prescribing professionals or to the nursing team through verbal or written means. Such interventions were considered as: (1) suggestion to change the pharmaceutical form; (2) suggestion to change the route of administration; (3) suggestion to change the medication; (4) guidance on enteral nutrition pause for medication administration. 
The classification categories of incompatibilities and interventions were elaborated by the authors based on the restrictions found in the literature of standardized medications to carry out the appointment with the team. The following sources were used: The Handbook of Enteral Feeding Tube, ${ }^{1}$ Pharmaceutical Care on drug administration via tubes: choice of the appropriate pharmaceutical form of the Albert Einstein Israeli Hospital ${ }^{4}$, Recommendations for drug administration via tubes of the Grande Dourados University Hospital, ${ }^{11}$ Administration of Oral Cytotoxic by Enteral Nutrition Tube of the São João Hospital Center, ${ }^{12}$ Manual of dilution and administration of medications through enteral accesses of the São Luiz Itaim Hospital, ${ }^{13}$ Acute Care Management of the HIV Infected Patient: A Report from the HIV Practice and Research Network of the American College of Clinical Pharmacy ${ }^{14}$ and the ANVISA Electronic Medications Compendium. ${ }^{10}$

In order to promote safety and quality in the administration of medications via enteral tubes, a table was prepared for consultation on the administration of medications via enteral tubes for the HU/UFSC, based on the same sources mentioned above. The table contains the name and presentation of the medications standardized by the institution, relevant observations indicated in the literature and availability in the hospital of another pharmaceutical form of the medication as an alternative route of administration.

The data were compiled and analyzed in a Microsoft Office Excel ${ }^{\circledR}$ spreadsheet. This study was approved by the Committee of Ethics in Research with Human Beings of UFSC and by the Teaching and Research Management of the HU/UFSC under protocol No. 3,334,699.

\section{Results}

In a six-month period, 47 prescriptions and 27 patients were included, containing 138 medications for administration via enteral feeding tubes at an urgency and emergency unit, resulting in a mean of approximately three medications per prescription. A total of $23(18.8 \%)$ medications presenting some incompatibility or restriction with this route of administration was identified. Interventions were carried out in $96 \%$ of the cases. The most prescribed medications with incompatibilities are shown in Table 1.

Table 1. Main medications with incompatibilities in the administration via tubes observed at the Professor Polydoro Ernani University Hospital of São Thiago, Santa Catarina, Brazil, 2019.

\begin{tabular}{ll}
\hline Medication & Frequency \% (n) \\
\hline Bisacodyl & $19.2(5)$ \\
Levothyroxine & $15.3(4)$ \\
Omeprazole & $11.5(3)$ \\
Levodopa + Benserazide & $11.5(3)$ \\
Ranitidine & $7.6(2)$ \\
Haloperidol & $7.6(2)$ \\
Atenolol & $3.8(1)$ \\
Phenytoin & $3.8(1)$ \\
Metoprolol & $3.8(1)$ \\
Metoclopramide & $3.8(1)$ \\
\hline
\end{tabular}

Considering the 23 medications prescribed with incompatibilities, $61.6 \%$ were related to the reduction or loss of efficacy of the drug, and another $30.8 \%$ was due to the interaction between drug and enteral nutrition. Pharmacokinetic changes and risk of tube obstruction accounted for $7.6 \%$ of the occurrences.

Regarding the interventions performed, $36 \%$ were suggestions to change the pharmaceutical form prescribed, $32 \%$ were related to guidelines on enteral nutrition pause, $24 \%$ were about the possibility of changing medications, and $8 \%$ recommended changing the route of administration (Table 2).

Table 2. Description of the main problems related to incompatibilities in the administration of medications via tubes and the interventions performed at the Professor Polydoro Ernani University Hospital of São Thiago, Santa Catarina, Brazil, 2019)

\begin{tabular}{ll}
\hline Variables & Frequency \% (n) \\
\hline Problems observed & $61.6(18)$ \\
Reduction or loss of efficacy & $30.8(8)$ \\
Drug-Nutrient interaction & $3.8(1)$ \\
Risk of tube obstruction & $3.8(1)$ \\
Pharmacokinetic change & \\
Interventions performed & $36.0(9)$ \\
Change in the pharmaceutical presentation & $32.0(8)$ \\
Guidance to pause enteral nutrition & $24.0(6)$ \\
Change of medications & $8.0(2)$ \\
Change of administration route &
\end{tabular}

The systematization of information about the safety of prescription and drug administration via tubes generated a chart containing 70 medications with some type of restriction or additional care for administration via tubes (Figure 1) based on the analysis of 181 medication available at the institution studied in the presentation of oral solids, in the following four different pharmaceutical forms: pills $(85 \%, n=154)$, capsules $(10.5 \%, n=19)$, powders $(2.8 \%, n=5)$, and dragees $(1.7 \%, n=3)$. Of the medications analyzed, $33.1 \%(60)$ had some restriction about administration via enteral feeding tubes. Among the restrictions, there was risk of tube obstruction in $30 \%$ (18) of the cases, lack of research studies ensuring efficacy and quality in $40 \%$ (24), pharmacokinetic change or loss of effect in $21.7 \%(13)$, and occupational risk in $8.3 \%$ (5), according to the databases searched. Additionally, $18.1 \%$ (10) of the medications required special attention when administering them, as they interacted with enteral nutrition and changed some pharmacokinetic aspects. These 70 medications and their respective recommendations for prescription are shown in Figure 1. For the vast majority of the examples, it is recommended to pause enteral nutrition one hour before and one hour after administration. However, it is worth highlighting some specificities, such as phenytoin and dolutegravir that require a two-hour pause after their administration to ensure total absorption of the medication, with no interferences. ${ }^{4,14}$

Among the medications with restrictions for administration via enteral feeding tubes, 35\% (21) presented another administration alternative in the institution. Of these alternatives, 33.3\% (7) were oral solutions or suspensions and $66.4 \%$ (14) were intravenous (IV) and intramuscular (IM) alternatives (Figure 1). 
Figure 1. Recommendations on enteral tube administration of the standardized medications at the Professor Polydoro Ernani University Hospital of São Thiago, Santa Catarina, Brazil, 2019. (Continued)

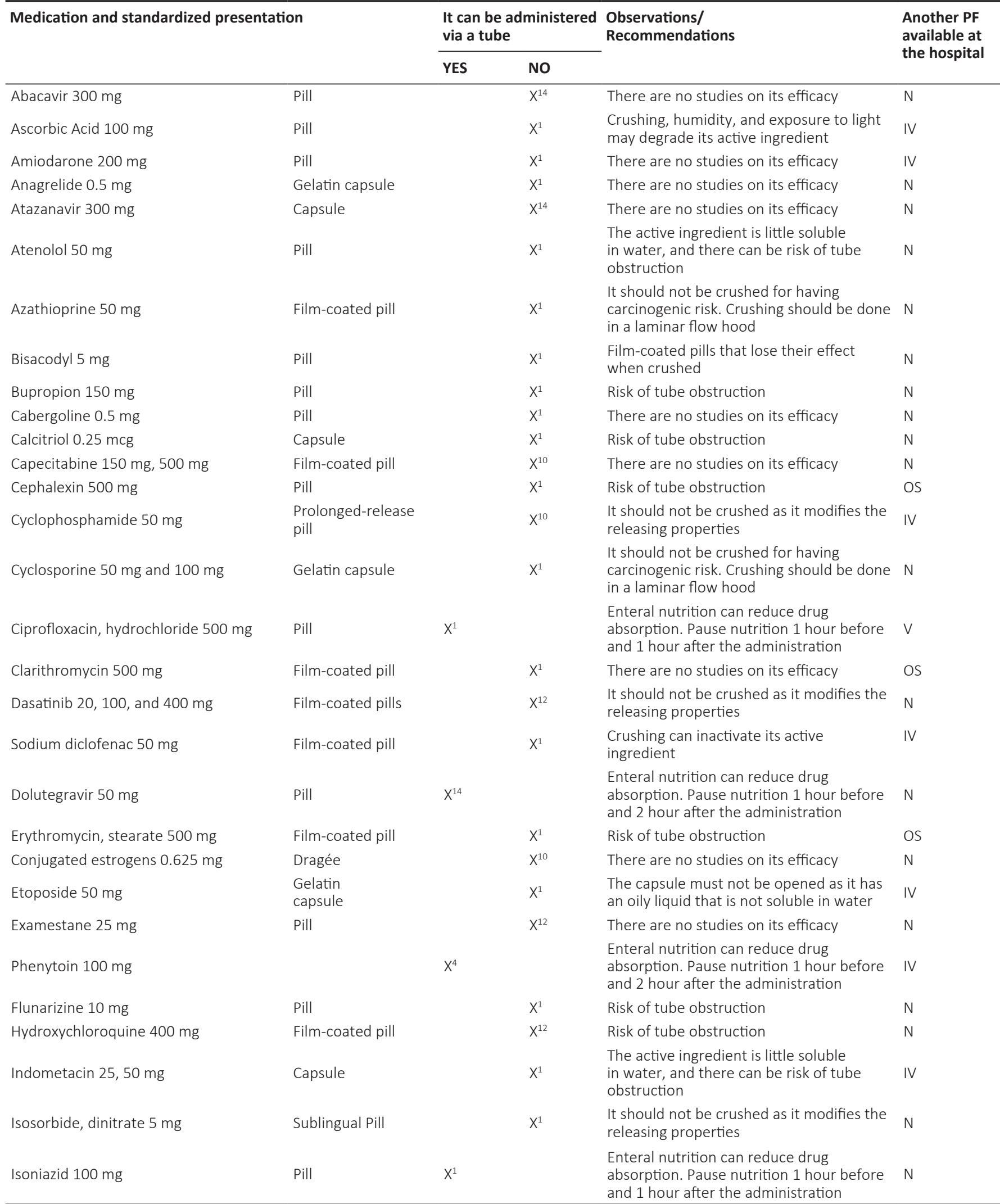


Figure 1. Recommendations on enteral tube administration of the standardized medications at the Professor Polydoro Ernani University Hospital of São Thiago, Santa Catarina, Brazil, 2019. (Continued)

\begin{tabular}{|c|c|c|c|c|c|}
\hline \multicolumn{2}{|l|}{ Medication and standardized presentation } & \multicolumn{2}{|c|}{$\begin{array}{l}\text { It can be administered } \\
\text { via a tube }\end{array}$} & \multirow{2}{*}{$\begin{array}{l}\text { Observations/ } \\
\text { Recommendations }\end{array}$} & \multirow{2}{*}{$\begin{array}{l}\text { Another PF } \\
\text { available at } \\
\text { the hospital }\end{array}$} \\
\hline & & YES & NO & & \\
\hline Itraconazole 100 mg & Pill & & $X^{1}$ & Risk of tube obstruction & $\mathrm{N}$ \\
\hline Ivermectin 6 mg & Pill & & $X^{1}$ & There are no studies on its efficacy & N \\
\hline $\begin{array}{l}\text { Levodopa } 200 \mathrm{mg}+\text { Benserazide, } \\
\text { hydrochloride } 50 \mathrm{mg}\end{array}$ & Pill & $X^{4}$ & & $\begin{array}{l}\text { Enteral nutrition can reduce drug } \\
\text { absorption. Pause nutrition } 1 \text { hour before } \\
\text { and } 1 \text { hour after the administration }\end{array}$ & N \\
\hline Levodopa 250 mg + Carbidopa 25 mg & Pill & $X^{4}$ & & $\begin{array}{l}\text { Enteral nutrition can reduce drug } \\
\text { absorption. Pause nutrition } 1 \text { hour before } \\
\text { and } 1 \text { hour after the administration }\end{array}$ & N \\
\hline Levofloxacin 500 mg & Film-coated pill & $X^{1}$ & & $\begin{array}{l}\text { Enteral nutrition can reduce drug } \\
\text { absorption. Pause nutrition } 1 \text { hour before } \\
\text { and } 1 \text { hour after the administration }\end{array}$ & IV \\
\hline Levonorgestrel $0.75 \mathrm{mg}$ & Pill & & $X^{10}$ & There are no studies on its efficacy & N \\
\hline Sodium levothryroxine 25 mcg, 100 mcg & Pill & $X^{1}$ & & $\begin{array}{l}\text { Enteral nutrition can reduce drug } \\
\text { absorption. Pause nutrition } 1 \text { hour before } \\
\text { and } 1 \text { hour after the administration }\end{array}$ & N \\
\hline Lopinavir 200 mg + Ritonavir 50 mg & Film-coated pill & & $X^{1}$ & There are no studies on its efficacy & OS \\
\hline Methylergometrine, maleate 0.125 mg & Pill & & $X^{10}$ & There are no studies on its efficacy & IV \\
\hline Metoprolol, succinate 25 mg & $\begin{array}{l}\text { Controlled-release } \\
\text { film-coated pill }\end{array}$ & & $x^{10}$ & $\begin{array}{l}\text { It should not be crushed as it modifies the } \\
\text { releasing properties }\end{array}$ & $\mathrm{N}$ \\
\hline Methotrexate $2.5 \mathrm{mg}$ & Pill & & $X^{1}$ & $\begin{array}{l}\text { It must not be crushed as it has carcinogenic } \\
\text { risk. Crushing should be done in a laminar } \\
\text { flow hood }\end{array}$ & IV \\
\hline Mycophenolate Mofetil 500 mg & Film-coated pill & & $X^{1}$ & $\begin{array}{l}\text { It must not be crushed as it has } \\
\text { carcinogenic risk and its excipients can } \\
\text { cause tube obstruction. Crushing should } \\
\text { be done in a laminar flow hood }\end{array}$ & N \\
\hline Sodium mycophenolate 180 mg, 360 mg & Film-coated pill & & $X^{1}$ & $\begin{array}{l}\text { It must not be crushed as it has } \\
\text { carcinogenic risk and its excipients can } \\
\text { cause tube obstruction. Crushing should } \\
\text { be done in a laminar flow hood }\end{array}$ & N \\
\hline Psyllium Mucilloid & Powder & & $X^{13}$ & Risk of tube obstruction & $\mathrm{N}$ \\
\hline Nifedipin 10 mg & Pill & & $X^{1}$ & Risk of tube obstruction & N \\
\hline Nifedipin 20 mg (Retard) & $\begin{array}{l}\text { Controlled-release } \\
\text { pill }\end{array}$ & & $X^{1}$ & $\begin{array}{l}\text { It should not be crushed as it modifies the } \\
\text { releasing properties }\end{array}$ & N \\
\hline Nimopidine 30 mg & Film-coated pill & & $X^{1}$ & There are no studies on its efficacy & $\mathrm{N}$ \\
\hline Norethisterone, acetate 10 mg & Pill & & $X^{10}$ & There are no studies on its efficacy & $\mathrm{N}$ \\
\hline Norfloxacin 400 mg & Film-coated pill & $x^{13}$ & & $\begin{array}{l}\text { Enteral nutrition can reduce drug } \\
\text { absorption. Pause nutrition } 1 \text { hour before } \\
\text { and } 1 \text { hour after the administration }\end{array}$ & N \\
\hline Omeprazole 20 mg, 40 mg & Capsule & & $X^{1}$ & Risk of tube obstruction & IV \\
\hline Ondansetron 4 mg & Orodispersible pill & & $X^{1}$ & Sublingual use, orodispersible pill & IV \\
\hline Pentoxifylline 400 mg & Film-coated pill & & $X^{10}$ & There are no studies on its efficacy & $\mathrm{N}$ \\
\hline Pindolol 5 mg & Pill & & $X^{11}$ & There are no studies on its efficacy & $\mathrm{N}$ \\
\hline Calcium polystyrene sulfonate 30 mg & Powder & & $X^{13}$ & Risk of tube obstruction & $\mathrm{N}$ \\
\hline Propatyl nitrate 10 mg & Pill & & $X^{10}$ & Sublingual use, orodispersible pill & N \\
\hline Ranitidine 150 mg, 300 mg & Pill & & $X^{11}$ & Risk of tube obstruction & IV \\
\hline Rifampicin 300 mg & Pill & & $X^{1}$ & There are no studies on its efficacy & OS \\
\hline Rifampicin 150 mg + Isoniazid 75 mg & Pill & & $X^{10}$ & There are no studies on its efficacy & $\mathrm{N}$ \\
\hline $\begin{array}{l}\text { Rifampicin } 150 \mathrm{mg}+\text { Isoniazid } 75 \mathrm{mg} \\
\text { + Pyrazinamide } 400 \mathrm{mg}+ \\
\text { Ethambutol } 275 \mathrm{mg}\end{array}$ & Pill & & $X^{10}$ & There are no studies on its efficacy & $\mathrm{N}$ \\
\hline Ritonavir 100 mg & Film-coated pill & & $X^{1}$ & There are no studies on its efficacy & $\mathrm{N}$ \\
\hline $\begin{array}{l}\text { Sulfamethoxazole }+ \\
\text { Trimethoprine } 400+80 \mathrm{mg}\end{array}$ & Pill & & $X^{1}$ & Risk of tube obstruction & IV/OS \\
\hline
\end{tabular}


Figure 1. Recommendations on enteral tube administration of the standardized medications at the Professor Polydoro Ernani University Hospital of São Thiago, Santa Catarina, Brazil, 2019. (Conclued)

\begin{tabular}{|c|c|c|c|c|c|}
\hline \multicolumn{2}{|c|}{ Medication and standardized presentation } & \multicolumn{2}{|c|}{$\begin{array}{l}\text { It can be administered } \\
\text { via a tube }\end{array}$} & \multirow{2}{*}{$\begin{array}{l}\text { Observations/ } \\
\text { - Recommendations }\end{array}$} & \multirow{2}{*}{$\begin{array}{l}\text { Another PF } \\
\text { available at } \\
\text { the hospital }\end{array}$} \\
\hline & & YES & NO & & \\
\hline Sulfasalazine $500 \mathrm{mg}$ & Film-coated pill & & $X^{1}$ & Crushing can inactivate its active ingredient & $\mathrm{N}$ \\
\hline Ferrous sulfate $40 \mathrm{mg}$ & Film-coated pill & & $\mathrm{X}^{1}$ & Risk of tube obstruction and oxidation & OS \\
\hline Tamoxifen 20 mg & Pill & & $X^{1}$ & There are no studies on its efficacy & $\mathrm{N}$ \\
\hline Tenoxicam 20 mg & Pill & & $X^{1}$ & Risk of tube obstruction & IV \\
\hline Thiamazole $10 \mathrm{mg}$ & Pill & & $X^{1}$ & There are no studies on its efficacy & $\mathrm{N}$ \\
\hline Tretinoin $10 \mathrm{mg}$ & Capsule & & $X^{1}$ & $\begin{array}{l}\text { Gelatin capsules must not be crushed, } \\
\text { little soluble in water }\end{array}$ & $\mathrm{N}$ \\
\hline Sodium warfarin $5 \mathrm{mg}$ & Pill & $X^{1}$ & & $\begin{array}{l}\text { Enteral nutrition can change absorption. } \\
\text { Pause enteral nutrition } 1 \text { hour before and } \\
1 \text { hour after the administration. }\end{array}$ & $\mathrm{N}$ \\
\hline B-complex vitamins & Dragée & & $X^{1}$ & Risk of tube obstruction & IV \\
\hline Zidovudine 100 mg & Capsule & & $X^{1}$ & There are no studies on its efficacy & OS \\
\hline
\end{tabular}

Key: PF: Pharmaceutical Form; IV: Intravenous; OS: Oral Suspension Solution; N: No; X: in column "NO", it indicates that it cannot be performed via enteral feeding tubes. Subscript number: see the list of references.

\section{Discussion}

Considering the data included in this study, it was possible to identify the prescription of medications (18.8\%) contraindicated for administration via enteral feeding tubes. This result points to the team's lack of knowledge about the incompatibility problem of the pharmaceutical products. In these cases, it was possible to perform interventions together with prescribing physicians and Nursing staff (nurses and nursing technicians) to ensure quality and safety in pharmacotherapy administration.

Research studies developed with this theme bring different results regarding the contraindication of drug administration via tubes and tend to be proportionally related to the number of medications analyzed. A study carried out in an infectology institute in Rio de Janeiro (Brazil) analyzed 236 medications, and 15\% of the prescribed drugs were not recommended for administration via enteral feeding tubes. ${ }^{15}$ At another university hospital, in Paraná (Brazil), a research study that analyzed 585 prescriptions with 1,817 medications for administration via enteral feeding tubes found errors in 786 (43.25\%) of the medications prescribed and indicated 574 pharmaceutical interventions perfomed. ${ }^{2}$

Another study carried out in Turkey pointed out that $40.5 \%$ of the medications administered via enteral feeding tubes were conducted incorrectly and that $17 \%$ of the nurses and $24 \%$ of the physicians knew that formulations with enteral coating cannot be crushed. ${ }^{16}$ A case report published by Iranian authors identified lack of professional knowledge about the prescription and, consequently, of drug administration through this route, causing harms to the patients. ${ }^{17}$ These research studies reflect the knowledge shortage of the professionals involved in health care and indicate the importance of adequate training to prevent errors.

Among the preparation processes of medications for administration via enteral feeding tubes, crushing is highlighted. This process changes the biopharmaceutical properties of medications, which can interfere in their absorption and increase or decrease their effect. ${ }^{18}$ An option to avoid crushing is using the same medications with the active ingredient in another pharmaceutical form (e.g., oral, intravenous solution). The study by Sohrevardi et al ${ }^{19}$ showed that $35.5 \%$ of the medications prescribed in an intensive care unit could be replaced by oral or intravenous solutions. In this Iranian study, approximately $61 \%$ of the restrictions for drug administration observed in the prescriptions were related to loss or reduction of medication efficacy, and 30\% presented some interaction with enteral nutrition. It was possible to intervene with the change of pharmaceutical form in $36 \%$ of the cases, optimizing the administration process and ensuring therapy efficacy. ${ }^{19}$

The five most prescribed medications that presented some restriction for administration in the hospital under study were bisacodyl, levothyroxine, omeprazole, levodopa + benserazide, and ranitidine. The administration of bisacodyl and omeprazole via tubes is related to loss of effect; as an alternative for these medications, other laxatives such as mineral oil and lactulose can be used, as well as ranitidine oral solution to replace omeprazole, respectively. ${ }^{1}$ Levothyroxine and levodopa + benserazide showed interaction with enteral nutrition, also resulting in the reduction of their therapeutic effect. Of these medications, only ranitidine could be replaced by an oral solution that was available in the hospital standardization. .,11 $^{-1}$

Only $3.8 \%$ of the medications prescribed presented risk of tube obstruction. Tube obstruction is a frequent complication that can be caused by inadequate preparation of drugs for administration, in addition to contraindications related to pharmaceutical formulations. ${ }^{3}$ A retrospective study analyzed that $34.7 \%$ of the medications prescribed by enteral route could have been replaced to reduce the risk of tube obstruction. ${ }^{20}$ The pharmaceutical interventions performed in this scenario are extremely important considering the implications that can be caused by the non-recommendation of administration, ensuring the correct selection of pharmaceutical forms and the most adequate route of administration. ${ }^{19}$

In this analysis, some type of intervention was performed in $96 \%$ of the cases to optimize the processes of drug prescription and administration via enteral feeding tubes. Gaps in the knowledge of the health professional about this theme suggest vulnerability in care and risk of harms to patients' health. ${ }^{21}$ Knowledge about the incompatibilities in this way of administration of oral medications and provision of easyaccess information in the hospitals can contribute to the safety of this practice. ${ }^{22}$ Additionally, professional qualification programs improve quality of care, helping to prevent future problems. ${ }^{23}$ Thus, it is believed 
that the method used for the development of the material with information on the administration of medications via tubes, proposed in this study, could be applied to the preparation process of drug administration by this route in other institutions. Skills and knowledge about administration techniques have repercussions on the quality of the care provided to the patients and on their safety. ${ }^{24}$

A study carried out in 2006 in two hospitals in New Zealand showed that the implementation of a multidisciplinary program for correct drug administration in patients with enteral tubes contributed to a reduction in the number of obstructed tubes and to fewer problems related to medications and administration errors by the nursing team. ${ }^{9}$

Among the 181 medications standardized in the study hospital, $33.1 \%$ presented some type of restriction for administration via tubes. It is important to highlight that $40 \%$ of these restrictions occurred due to lack of research studies and information ensuring safety and efficacy of the medication's therapeutic effect. The study by Carvalho et $\mathrm{al}^{7}$ showed that $17.8 \%$ of the medications prescribed via enteral feeding tubes did not have information available in the literature about their administration by this route. This shows the lack of information provided by the manufacturers themselves about the possibility of drug administration via tubes, being a limitation of the present study which hinders research studies in this scenario. ${ }^{25}$

In this context, it is necessary that the health services together with nurses, pharmacists and physicians, provide instructions and training to ensure good practices of prescription of medications and preparation of these formulations by the nursing team to minimize possible effects that may harm the patient's therapy and health. Permanent training programs with the team to ensure inter-professional practice among pharmacists, physicians and nursing staff are important actions in this process. ${ }^{26}$

This study has some limitations: As it is a sample chosen by convenience, the data obtained were restricted to the standardized medications in the institution under study, with the exclusion of non-standardized medications that could interfere in the results. Additionally, the databases consulted were limited to studies available for free. These aspects should be considered by professionals and researchers involved in this field.

\section{Conclusion}

The research carried out indicated that almost $20 \%$ of the medications prescribed during six months for administration via enteral feeding tubes presented some incompatibility in an emergency unit in the South of the country. Considering that the pharmaceutical interventions are necessary to reduce future problems that erroneous drug administration via enteral feeding tubes can cause, the results showed that it was possible to intervene after the analysis of prescriptions in a Brazilian emergency unit, contributing to the reduction of errors and risks associated with pharmacotherapy. The present study showed the importance of evaluating prescriptions containing medication by this route for the cases studied.

The development of supporting material for drug administration via tubes is a strategy to ensure the quality of the drug therapy under these conditions. In addition, it is necessary that the health institutions provide the collaborators with continuing education for the management of these situations and that the professionals work collaboratively to ensure treatment effectiveness.

\section{Funding sources}

The research did not receive any funding for its realization.

\section{Collaborators}

IAS and FCM built the project; IAS conducted data collection. IAS and FMC analyzed and interpreted the data, in addition to elaborating and critically reviewing the article. The authors assume full responsibility for the data published and guarantee the accuracy and integrity of the article.

\section{Acknowledgments}

The authors would like to thank the Hospital Pharmacy team of the University Hospital of the Federal University of Santa Catarina for their collaboration.

\section{Conflict of interests statement}

The authors declare that there are no conflicts of interests in relation to this article.

\section{References}

1. White R, Bradnam V. Handbook of Drug Administration via Enteral Feeding Tubes, 3 edição. Londres: Pharmaceutical Press; 2015.

2. Ferreira-Neto CJB, Plodek CK, Soares FK, et al. Pharmaceutical interventions in medications prescribed for administration via enteral tubes in a teaching hospital. Rev Lat Am Enfermagem. 2016;24(0):1-9.

3. Fernanda REG, Rosana $\mathrm{AP}, \mathrm{Ana} \mathrm{CPH}$, et al. Medication incidents related to feeding tube: A cross-sectional study. African J Pharm Pharmacol [Internet]. 2017;11(27):305-13.

4. Lima G, Negrini NMM. Assistência farmacêutica na administração de medicamentos via sonda: escolha da forma farmacêutica adequada. Einstein. 2009;7(0):9-17.

5. Schier JG, Howland MA, Hoffman RS, et al. Fatality from administration of labetalol and crushed extended-release nifedipine. Ann Pharmacother. 2003;37(10):1420-3.

6. Barbosa DL, Miguel SS, Cornélio RCAC, et al. Interações fármaco-nutrição enteral em unidade de terapia intensiva: determinação de prevalência e significância clínica A Artigo Original. Braspen. 2018;33(1):49-53.

7. Carvalho AMR, Oliveira DC, Neto JEDH, et al. Análise Da Prescrição De Pacientes Utilizando Sonda Enteral Em Um Hospital Universitário Do Ceará. Rev Bras Farmácia Hosp e Serviços Saúde. 2010;1(1):17-21.

8. Gimenes FRE, Anacleto TA. Preparo e administração de medicamentos via sonda enteral ou ostomias. Bol ISMP-Brasil. 2015;4(4):1-5.

9. Van-Den-Bemt PMLA, Cusell $\mathrm{MBI}$, Overbeeke PW, et al. Quality improvement of oral medication administration in 
patients with enteral feeding tubes. Qual Saf Heal Care. 2006;15(1):44-7

10. Agência Nacional de Vigilância Sanitária. ANVISA. Bulário Eletrônico. Available at: http://www.anvisa.gov.br/datavisa/ fila_bula/frmResultado.asp\#. Accessed on: November 10, 2019

11. Universidade Federal de Grande Dourados. Recomendações para administração de medicamentos via sonda. Ebserh. 2017;1-17.

12. Ferreira S. Administração de Citotóxicos Orais por Sonda de Nutrição Entérica. 2012;1(0):69-77.

13. Ferrer R, Joaquim FM, Pavan A, et al. Manual de diluição e administração de medicamentos por acessos enterais. Braspen J. 2019;34(2):193-212

14. Durham SH, Badowski ME, Liedtke MD, et al. Acute Care Management of the HIV-Infected Patient: A Report from the HIV Practice and Research Network of the American College of Clinical Pharmacy. Pharmacotherapy. 2017;37(5):611-29.

15. Silva MFB, Brito PD, Guaraldo L. Oral drugs at a hospital unit: adequacy for use via enteral feeding tubes. Rev Bras Enferm. 2016;69(5):847-54.

16. Demirkan K, Bayraktar-Ekincioglu A, Gulhan-Halil M, et al. Assessment of drug administration via feeding tube and the knowledge of health-care professionals in a university hospital. Eur J Clin Nutr. 2017;71(2):164-8.

17. Hamishehkar H, Mahmoodpoor A, Mashayekhi S, et al. Errors of oral medication administration in a patient with enteral feeding tube. J Res Pharm Pract. 2012;1(1):37-40.

18. Jory C, Shankar R, Oak K, et al. Going down the tubes! Impact on seizure control of antiepileptic medication given via percutaneous feeding tubes. Epilepsy and Behavior. 2017;74(0):114-118

19. Sohrevardi S, Jarahzadeh M, Mirzaei E, et al. Medication errors in patients with enteral feeding tubes in the intensive care unit. J Res Pharm Pract. 2017;6(2):1-8.

20. Silva MJS, Cava CEM, Pedroso PK, et al. Evaluation of the profile of drug therapy administered through enteral feeding tube in a general hospital in Rio de Janeiro. Brazilian J Pharm Sci. 2011;47(2):331-7.

21. Figueiredo PP, Santos LM, Silveira RS, et al. Elaboration of instrument to know practice of preparation and administration of drugs via enteral feeding tube by nursing professionals. Rev Pesqui Cuid é Fundam. 2018;10(2):299-309.

22. Matysiak-Luśnia K, Łysenko L. Drug administration via enteral feeding tubes in intensive therapy - terra incognita? Anaesthesiol Intensive Ther. 2014;46(4):307-11.

23. Nascimento MMG, Reis AMM, Wick JY, et al. Administración de fármacos através de las sondas de alimentación: Un programa integrado de cualificación. Nutr Hosp. 2012;27(4):1309-1313.

24. Sari D, Kadifeli $D$, Akbiyik A, et al. Intensive care unit nurses' knowledge of medication administration via enteral tubes. Nurs Crit Care. 2018;23(3):141-6.

25. Li T, Eisenhart A, Costello J. Development of a medication review service for patients with enteral tubes in a community teaching hospital. American J Health-System Pharm. 2017;74(11):47-51

26. Alhashemi SH, Ghorbani R, Vazin A. Improving knowledge, attitudes, and practice of nurses in medication administration through enteral feeding tubes by clinical pharmacists: a casecontrol study. Adv Med Educ Pract. 2019;10(0):493-500. 